\title{
Measurements of selected greenhouse gases exhalation by using the closed-chamber technique and calculation of hour expiration with regard to $\mathrm{CO}_{2}$ emissions*
}

\section{Pomiar eksahalacji wybranych gazów cieplarnianych za pomocą komory zamkniętej oraz obliczanie wielkości emisji godzinowej na przykładzie wydzielania $\mathrm{CO}_{2}$}

Abstract:

The article presents the use of a closed-chamber method used for measuring the size of exhalation gases from the soil. The paper presents the assumptions of the method, the measuring kit and information regarding the conversion of the gas concentration in the measuring chamber into the amount of gases emitted from the soil. The authors presented a way of converting concentration of emission gases (for example $\mathrm{CO}_{2}$ ) in [ppm] units into the exhalation values $\left[\mathrm{mg}\left(\mathrm{CO}_{2}\right) \times \mathrm{m}^{-2} \times \mathrm{h}^{-1}\right.$, which are more convenient for comparing the results of environmental tests. The work also includes guidelines for conducting the field measurements and allows one to estimate the size of the exchange of gases between soil and atmosphere.

Key words: closed-chamber method, soil respiration, $\mathrm{CO}_{2}$ expiration, gas analyzer.

Zarys treści: $\quad$ Artykuł prezentuje zastosowanie metody komorowej, przy wykorzystaniu statycznej komory zamkniętej, służącej do pomiarów wielkości ekshalacji gazów z gleby. W pracy przedstawiono założenia metody, skład zestawu pomiarowego oraz informacje dotyczące przeliczania wartości stężenia gazów w komorze pomiarowej na ilość gazów. Autorzy zaprezentowali sposób przeliczania stężenia gazów (na przykładzie $\mathrm{CO}_{2}$ ) w jednostkach [ppm] na wartości ekshalacji $\left[\mathrm{mg}\left(\mathrm{CO}_{2}\right) \times \mathrm{m}^{-2} \times \mathrm{h}^{-1}\right.$ ], które są wygodniejsze do porównań wyników badań środowiskowych. Praca zawiera ponadto wskazówki dla prowadzenia pomiarów terenowych i pozwala na szacowanie wielkości wymiany gazów pomiędzy glebą i atmosferą.

Słowa kluczowe: metoda komorowa zamknięta, respiracja gleb, wydzielanie $\mathrm{CO}_{2}$, analizator gazów.

\section{Introduction}

Gas exchange that occurs between soil and atmosphere is an important element of the circulation of certain elements in the environment (Parkin, Kaspar 2004; Maljanen et al. 2004; Paul 2007). An important scientific problem is the precision of gases emission measurement. While the methodology of such measurements is relatively well understood, the determination of greenhouse gases emission into the atmosphere poses a challenge for today's science, mainly due to the high variability of the release of gases from soils in a function of time. Another important issue is the ability to determine the size of exhalation while maintaining the momentum of this process depends on the time of the day, temperature, atmospheric pressure, and even humidity (Fang, Moncrieff 2001; Parkin, Kaspar 2003; Schneider et al. 2009; Koskinen et al. 2014; Riederer et al. 2014). For many researches techniques that base on a chemical reaction are succesfully used (Krysiak et al. 2010; Papińska et al. 2010; Tołoczko, Niewiadomski 2010), but primarily on the gradient methods involving the measurement of gas concentrations using gauges dedicated only to one of gases or multi-gas analyzers (Jenses et

* The article is financed by National Science Centre within the pro ject 2011/01/B/ST10/07550 „Bilans absorpcji i emisji gazów cieplarnianych (metanu, dwutlenku węgla i pary wodnej) na obszarach bagiennych (stadium Biebrzańskiego Parku Narodowego)". The balance of absorption and emission of greenhouse gases (methane, carbon dioxide and water vapor) on the swamps (stage Biebrza National Park) al. 1996; Bekku et al. 1997; Norman, et al. 1997; Janssens et al. 2000; Pumpanen et al. 2004; Turcu et al. 2005; Chojnicki et al. 2010; Pereira, Salcedo 2012).

This article presents an easy way to determine the level of gas emissions from the soil on the basis of closed-static chamber measurements and multi-gas gauges.

\section{Method description}

The presented methodology for determination of greenhouse gas emissions from soil to the atmosphere bases on time dependent measurement of their concentration in the chamber localized directly on the ground. Test measurements were performed both on mineral soils and on organic soils with varying degrees of humidity and cohesion (from peat through the sands for clay structures). The measuring set is biult in a way which allows for research on any porous substrate.

The kit includes measuring devices available on the market, but the design of their use (fig. 1) was created in the Department of Physical Geography, University of Lodz.

- Steel square frame with an outer side length of $25 \mathrm{~cm}$ and an internal $21 \mathrm{~cm}$, which is the basis of the chamber. The frame consists of $4 \mathrm{U}$-shaped drainpipes with a width of $2 \mathrm{~cm}$ from the bottom with a welded $3 \mathrm{~cm}$ flange to allow static positioning of the frame in the ground. It can be driven into the ground with the weight of a human body - making it thereon. The flange steel frame cuts to 
study the fragment surface of the ground measuring $23 \mathrm{~cm}$ by $23 \mathrm{~cm}$.

- The frame is made of steel wire with a diameter of $2 \mathrm{~mm}$, on which are placed the gas concentration gauges. Our gas gauge comes from the microwave oven. To keep the same distance from the ground the gas gauge is to be placed at the feet in a steel drainpipe before each measurement.

- The transparent chamber made of plexiglass with sides of length $23 \mathrm{~cm}$ and a height of $20 \mathrm{~cm}$, which gives a total area of $0.0529 \mathrm{~m}^{2}$ and the volume of $0.01058 \mathrm{~m}^{3}$. Five walls have been carefully and tightly glued and the sixth wall is an active ground surface under investigation.

- In the chamber is installed a small computer fan supporting the diffusion of gases and preventing their stratification, which without its use would be possible due to the fact that the weight of carbon(IV) monoxide $\left(\mathrm{CO}_{2}\right)$ is approx. 1.5 times higher than the weight of the air. The issue was studied under the guidance of Kusa et al. (2008). To one side of the chamber is attached with an adhesive the connector RJ-9 to power the fan. Wires of fan are led outside the chamber through a small hole in it and have been carefully pasted, which provided the tightness of the measuring chamber. A $12 \mathrm{~V}$ battery was used to power the fan. The described chamber is applied directly onto the frame installed in the ground. In order to seal the assembly, water is poured into the drainpipe.

- The measuring instruments used in investigations were in the form of three multi-gas gauges, which are based on measuring of the concentration of gases that have the ability to absorb electromagnetic waves in the infrared range. The amount and type of gauges used is arbitrary (unlimited) and depends only on the type and accuracy of measurements. The gauges used for determining the exhalation of selected greenhouse gases the following were used: Wide Range (0-6000 ppm) $\mathrm{CO}_{2}$ concentration gauge AirTech Vento with a slot module of air temperature measurement, multi-gas gauge Multigas III.4 by Ewimar-WB with 3 probes $-\mathrm{CO}_{2}, \mathrm{SO}_{2}$ and $\mathrm{NO}_{2}$ and $\mathrm{MX} 6$ iBrid multi-gas gauge by Industrial Scientific with 4 probes $-\mathrm{CH}_{4}$, $\mathrm{NH}_{3}, \mathrm{H}_{2} \mathrm{~S}$ and VOCs (Volatile Organic Compounds).

- The entire apparatus is supplemented with a glass thermometer, which is placed into the ground next to the measuring chamber to measure simultaneously the exaltation of the gases in the chamber as well as temperature of the investigated soil. Vento AirTech gauge showed the temperature inside the chamber with an accuracy of $\pm 0.1^{\circ} \mathrm{C}$, which increased during the measurement usually by about $2-3^{\circ} \mathrm{C}$. In order to verify if that affects the temperature increase of the device, a glass thermometer has been left inside the chamber next to the gauges.

The system is deployed entirely on relatively flat ground. The frame must be potted in soil, which prevents the escape of gases under the frame. It must lay flat on the ground because of the need to fill with water. Water acts as a seal between the steel frame and shade of plexiglass. During the measurements chamber was not covered to allow for normal photosynthesis. In case of conducting measurements for several months, a particular attention was paid to install a set each time in the same place.

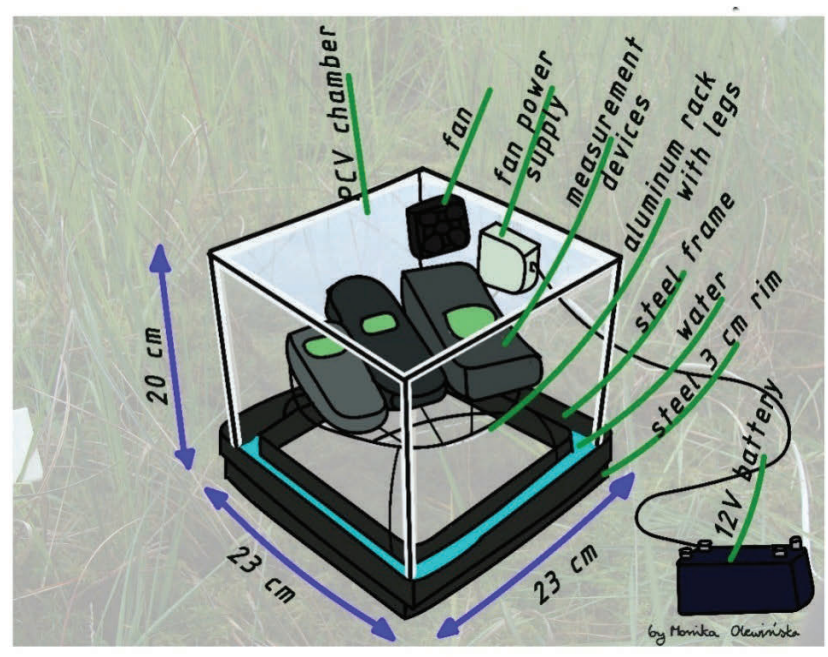

Fig. 1. Schematics of the measuring chamber

Rys. 1. Schemat komory pomiarowej

\section{Calculation of results}

Assumptions of the method:

It is well known that 1 mole of gas occupies a volume of $22.4 \mathrm{dm}^{3}$, which is $0.0224 \mathrm{~m}^{3}$. This would imply that in $1 \mathrm{~m}^{3}$ of atmospheric air is 44.64 moles of all gases included in the air. This assumption is valid only for an ideal gas under normal conditions, that is, for $\mathrm{T}=273[\mathrm{~K}]$ and with a pressure $p=1013$ [hPa] (tab. 1). The measurement of gas exhalation from the soil to the atmosphere is performed under the assumption that the volume of the gas will be variable dependent on thermal and atmospheric pressure conditions. The correctness of these considerations is based on the ideal gas law and Clapeyron's equation:

where :

$$
p V=n R T
$$

$p$-atmospheric pressure [Pa] i.e. $101300[\mathrm{~Pa}]=1013$ [hPa],

$V$ - gas volume $\left[\mathrm{m}^{3}\right]$ i.e. $1\left[\mathrm{~m}^{3}\right]$,

$n$ - number of gas moles [mole] (which is a measure of the number of molecules),

$R$ - universal gas constant $R=N_{A} \cdot k_{B}$, where: $N_{A}-$ Avogadro's number, $k B-$ Boltzmann's constant, $R=8.314$ $\left[\mathrm{J} \times \mathrm{mole}^{-1} \times \mathrm{K}^{-1}\right]$,

$T$ - absolute temperature $[\mathrm{K}]=\mathrm{T}\left[{ }^{\circ} \mathrm{C}\right]+273$.

This equation was derived based on the following assumptions:

- The gas consists of moving particles,

- Particles collide with each other and with the walls of the vessel in which they are located,

- Interactions in the analyzed gas are not present, except repulsion at the time of collision of particles,

- The volume (size) of particles is ignored,

- Collisions of molecules are perfectly elastic.

Real gases show minor deviations from the above equation, but in terms of temperature and pressure conditions in winter and summer they are meaningless. As environmental testing is carried out usually in the 
temperature range (from $-10^{\circ} \mathrm{C}$ to $+40^{\circ} \mathrm{C}$ ) and atmospheric pressure (990-1040 hPa) thus from Clapeyron's equation it can be calculated exactly how many moles of the gas is $1 \mathrm{~m}^{3}$ or in a given volume of the measuring chamber having a gases temperature in the chamber and their pressure:

$$
\begin{array}{cl}
n=\frac{p V}{R T} & \text { ning energy distribution of molecul } \\
& {\left[\mathrm{J} \times \mathrm{K}^{-1}\right] . \text { Hence the gas constant is }} \\
& \left.\times \mathrm{K}^{-1}\right] . \text { In order to check whether the } \\
& \text { one should calculate: }
\end{array}
$$

For each determination of the amount of gases in the soil there is a need to make a calculation taking into account the measured temperature and the prevailing atmospheric pressure. Ranging temperature and pressure affect the high variability of the amount of $n$ moles of air at $1 \mathrm{~m}^{3}$ (tab. 1). This complicates the calculation. Let's see
In the environment we study, the atmospheric air is a mixture of gases ( $\mathrm{N}_{2}, \mathrm{O}_{2}, \mathrm{Ar}, \mathrm{CO}_{2}$, water vapor et al.). Gas constant R in the Clapeyron's equation, is the product of Avogadro's number (physical constant numerically equal to number of molecules in 1 mole of gas and is $\mathrm{N}_{\mathrm{A}}=6.0221$ $\left.\times 10^{23}\left[\mathrm{~mole}^{-1}\right]\right)$ and the Boltzmann's constant determining energy distribution of molecules $k_{B}=1.3806 \times 10^{-23}$ $\left[\mathrm{J} \times \mathrm{K}^{-1}\right]$. Hence the gas constant is $\mathrm{R}=8.31\left[\mathrm{~J} \times \mathrm{mole}^{-1}\right.$ $\times \mathrm{K}^{-1}$. In order to check whether the result is given in mole

how Clapeyron's equation describes a number of moles of air in only 7 cases at a temperature from $-10\left[{ }^{\circ} \mathrm{C}\right]$ to $40\left[{ }^{\circ} \mathrm{C}\right]$ and a pressure from $990 \mathrm{hPa}$ to $1040 \mathrm{hPa}$ including in the summer conditions often encountered $18\left[{ }^{\circ} \mathrm{C}\right]$ and 1013 [hPa] (Example 1) and $23\left[^{\circ} \mathrm{C}\right]$ and 1019 [hPa] (Example 2). Results are presented in tab. 1.

\begin{tabular}{|c|c|c|c|c|c|c|c|}
\hline Number & $\mathrm{T}\left[{ }^{\circ} \mathrm{C}\right]$ & $T[\mathrm{~K}]$ & $\mathrm{p}$ [hPa] & $p[\mathrm{~Pa}]$ & $V\left[\mathrm{~m}_{3}\right]$ & $\begin{array}{c}R \\
{\left[\mathrm{~J} \times \mathrm{mole}^{-1} \times \mathrm{K}^{-1}\right]}\end{array}$ & $n$ [mole] \\
\hline 1 & 18 & 291 & 1013 & 101300 & 1 & 8.31 & 41.89 \\
\hline 2 & 23 & 296 & 1019 & 101900 & 1 & 8.31 & 41.39 \\
\hline 3 & 0 & 273 & 1013 & 101300 & 1 & 8.31 & 44.64 \\
\hline 4 & -10 & 263 & 990 & 99000 & 1 & 8.31 & 45.30 \\
\hline 5 & -10 & 263 & 1040 & 104000 & 1 & 8.31 & 47.59 \\
\hline 6 & 40 & 313 & 990 & 99000 & 1 & 8.31 & 38.06 \\
\hline 7 & 40 & 313 & 1040 & 104000 & 1 & 8.31 & 39.98 \\
\hline
\end{tabular}

Tab. 1. Number of $n$ moles of air in a volume of $1 \mathrm{~m}^{3}$ in the range of selected temperatures and pressures

Tab. 1. Liczba moli $n$ powietrza w $1 \mathrm{~m}^{3}$ przy zmiennych warunkach temperatury i ciśnienia

Source: own compilation.

Źródło: opracowanie własne.

The above calculations show that, with pressure in the range $990-1040$ [hPa], and a negative temperature such as $-10\left[{ }^{\circ} \mathrm{C}\right]$ in $1 \mathrm{~m}^{3}$ of air it will always be more than 44.64 moles of air, and during a hot day at $40\left[{ }^{\circ} \mathrm{C}\right]$ in the $1 \mathrm{~m}^{3}$ of air it will always be less than 44.64 mole of air (tab. 1). Weather conditions during days of measurements force recalculation of each obtained result with consideration of measuring temperature and atmospheric pressure. In addition to temperature and pressure measurements on the test bench the temperature inside the chamber which must also be included, should be as close as possible to the temperature outside the chamber.

The foregoing is intended to show how a large number of gas molecules can be found in the standard unit of volume, and as the variable is the amount depending on the current temperature and atmospheric pressure.

\section{Abbreviations and symbols}

Because of the large number of parameters used, below is a list of the most important shortcuts in the computational method part.
$E$ - exhalation $\left[\mathrm{mg}\left(\mathrm{CO}_{2}\right) \times \mathrm{m}^{-2} \times \mathrm{h}^{-1}\right]$,

$\Delta S$ - increase of concentration as the difference of indications from the gauge [ppm] - for the gas measurement (eg. $\mathrm{CO}_{2}$ ): it is the difference between the indication of the gauge in the measuring chamber after 13 minutes and 1 minute, eg.: $\Delta S=680[\mathrm{ppm}]-520[\mathrm{ppm}]=160[\mathrm{ppm}]$,

$H$ - measurement time - in this case it is: $H=13 \mathrm{~min}-$ $1 \mathrm{~min}=12$ [min],

60 - conversion of minutes to a full hour [ $\min \times \mathrm{h}^{-1}$ ],

$X$ - the conversion of $\Delta S$ measurement from minute measurement $H$ [min] to a full hour [h] - in this case it is: $X=H[\mathrm{~min}] / 60\left[\mathrm{~min} \times \mathrm{h}^{-1}\right]=12 / 60\left[\mathrm{~min} \times \min ^{-1} \times \mathrm{h}\right]=$ $12 / 60[\mathrm{~h}]=0.2[\mathrm{~h}]$,

$K$ - the area of chamber - in this case: $K=0.23[\mathrm{~m}]$ $\times 0.23[\mathrm{~m}]=0.0529\left[\mathrm{~m}^{2}\right]$,

$A$ - the volume of chamber - in this case: $A=K \times 0.2[\mathrm{~m}]$ $=0.01058\left[\mathrm{~m}^{3}\right]$,

$B$ - the volume of gauges in the chamber - in this case: $B=0.00089\left[\mathrm{~m}^{3}\right]$ (calculated by the authors based on the dimensions of used gauges), 
$C$ - the volume of air in the chamber - because $C=A-B$ than: $C=0.00969\left[\mathrm{~m}^{3}\right]$,

Mgas - mole mass of the investigated gas - eg.: $\mathrm{Mco}_{2}=$ $44.01\left[\mathrm{~g} \times \mathrm{mole}^{-1}\right], \mathrm{MNH}_{3}=17.03\left[\mathrm{~g} \times \mathrm{mole}^{-1}\right]$,

$n$ - number of gas moles (air) in $1 \mathrm{~m}^{3}$ from Clapeyron's equation $=44.64$ [mole],

$n \times 10^{-6}$ - one millionth part of any amounts expressed in [mole],

$n_{C}$ - the number of moles of gas (air) in the measuring chamber [mole],

$10^{-6}$ - conversion of concentration value on the volume fraction $\left[\mathrm{ppm}^{-1}\right]$,

$F$ - the number of moles of gas corresponding to $1 \mathrm{ppm}$ : $F=n \times 10^{-6}\left[\right.$ mole $\left.\times \mathrm{ppm}^{-1}\right]$.

Conversion of concentration value to the amount of released gases

In order to give a concentration of 1 [ppm] by volume percent it is sufficient to use the expression (multiplication): $\mathrm{F} \times 100[\%]=1[\mathrm{ppm}]$ volume fraction $\times 100[\%]$, so the concentration of $1[\mathrm{ppm}] \times 10^{-6}\left[\mathrm{ppm}^{-1}\right] \times 100[\%]=$ $1 \times 10^{-6} \times 100$ [\%]. On this basis, we determine that: $1 \mathrm{ppm}=0.0001 \%$, then $100 \mathrm{ppm}=0.01 \%$, and $1000 \mathrm{ppm}$ $=0.1 \%$. Mass of $1 \mathrm{ppm}\left(\mathrm{CO}_{2}\right)$ will be different for different volumes of gas. We must determine in which capacity we can measure the concentration and to which volume value it relates. In order to apply properly this relation, the mass of $1 \mathrm{ppm}$ of gas must be calculated, eg. in $1 \mathrm{~m}^{3}$ of air. Under normal conditions, in $1 \mathrm{~m}^{3}$ of air $\mathrm{n}=44.64$ moles of air. The mass of 1 mole of $\mathrm{CO}_{2}$ is $\mathrm{McO}_{2}=44.01\left[\mathrm{~g} \times\right.$ mole $\left.^{-1}\right]$. One can calculate the mass of $1 \mathrm{ppm}$ of $\mathrm{CO}_{2}$ in $1 \mathrm{~m}^{3}$ of air in milligrams. The mass is described by expression: $1[\mathrm{ppm}] \times F\left[\right.$ mole $\left.\times \mathrm{ppm}^{-1}\right] \times$ Mgas $\left[\mathrm{g} \times \mathrm{mole}^{-1}\right]=1[\mathrm{ppm}]$ $\times n$ [mole $] \times 10^{-6}\left[\mathrm{ppm}^{-1}\right] \times$ Mgas $\left[\mathrm{g} \times \mathrm{mole}^{-1}\right]=44.64$

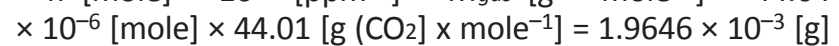
$=1.9646[\mathrm{mg}]$. This is to calculate the volume of $1 \mathrm{~m}^{3}$ of air and normal conditions is: $\mathrm{T}=0\left[{ }^{\circ} \mathrm{C}\right]=273[\mathrm{~K}]$ and the atmospheric pressure $p=101325[\mathrm{~Pa}]$. In the course of environmental measurements such conditions are rare, actually only during the mild winter. It can be assumed that the results will always require recalculation according to the Clapeyron's equation. Therefore, it is always necessary to correct the number of moles of gas in a volume declared e.g. $1 \mathrm{~m}^{3}$ or in a volume of the measuring chamber $A$ or $C$. The expression:

$$
\Delta S \times F\left[\mathrm{ppm} \times \text { mole } \times \mathrm{ppm}^{-1}\right]=\Delta S \times n \times 10^{-6}[\text { mole }]
$$

describes the number of moles of gas evolved (eg. $\left.\mathrm{CO}_{2}\right)$ in a given volume of air, i.e. in $1 \mathrm{~m}^{3}$ of air. It can be assumed that under normal conditions with an increase of $\Delta S$ value $\mathrm{CO}_{2}$ concentration of $1 \mathrm{ppm}$ in $1 \mathrm{~m}^{3}$ of air it will be 44.64 $\times 10^{-6}$ mole of this gas (i.e. $\mathrm{CO}_{2}$ ).

It is necessary to adjust (reduce) the volume of the measuring chamber by the volume occupied inside by: fan, wire frame and gauges inserted into the chamber. Since the volume of the empty chamber $A=0.01058 \mathrm{~m}^{3}$ is subtracted the calculated value $B=0.00089 \mathrm{~m}^{3}$, that is, the volume of said elements located under the transparent chamber made of plexiglass, which gives the actual volume of gas in the chamber $\mathrm{C}=0.00969 \mathrm{~m}^{3}$. This volume will increase when in the chamber is less measuring devices. Therefore, the number of moles of air in the measuring chamber will describe the equation:

$$
n_{C}=\frac{p C}{R T}=\frac{p \cdot 0,00969}{8,31 \cdot T}[\mathrm{~mol}]
$$

For each of the measuring result to be corrected to $1 \mathrm{ppm}$ in moles of gas, taking into account measurements of temperature and pressure. According to the formula above (at measured atmospheric pressure and temperature) it is necessary to calculate how many moles of air are in the measuring chamber for temperature $T=23\left[{ }^{\circ} \mathrm{C}\right]=296[\mathrm{~K}]$ and the atmospheric pressure $p=101900[\mathrm{~Pa}]$

$$
n_{C}=\frac{p C}{R T}=\frac{101900 \cdot 0,00969}{8,31 \cdot 296}[\mathrm{~mol}]=0,4014[\mathrm{~mol}]
$$

This value will vary for different weather conditions and must be adjusted on the fly. Now for the real conditions indicated it is easy to show that the mass of $1 \mathrm{ppm}$ of $\mathrm{CO}_{2}$ in the test chamber with its volume $\mathrm{C}$ is the expression: $1[\mathrm{ppm}] \times n c \times 10^{-6} \times \mathrm{McO}_{2}=0.4014[\mathrm{~mole}] \times 10^{-6}\left[\mathrm{ppm}^{-1}\right]$ $\times 44.01\left[\mathrm{~g}\left(\mathrm{CO}_{2}\right) \times \mathrm{mole}^{-1}\right]=17.6656 \times 10^{-6}\left[\mathrm{~g}\left(\mathrm{CO}_{2}\right)\right]$.

Summarizing the arguments, $1 \mathrm{ppm}$ of $\mathrm{CO}_{2}$ in the measuring chamber described above under given conditions, has a weight close to 0.0177 [ $\left.\mathrm{mg}\left(\mathrm{CO}_{2}\right)\right]$. When $\Delta S$, the concentration of $\mathrm{CO}_{2}$ in the chamber is increased by $1 \mathrm{ppm}$, this means that the rise was approx. 0.0177 [mg (CO2)]. Changing atmospheric conditions appreciably affect the mass of $1 \mathrm{ppm}$ of evolved gas $\left(\mathrm{CO}_{2}\right)$. Further considerations will lead to determining the size of the $\mathrm{CO}_{2}$ exhalation per unit area $\left(1 \mathrm{~m}^{2}\right)$ at a given time $(1 \mathrm{~h})$.

\section{Calculation of exhalation}

In studies of exhalation E - emission gas value - it is common to indicate the amount of gas evolved per unit area at a specified time $\left[\mathrm{mg}\left(\mathrm{CO}_{2}\right) \times \mathrm{m}^{-2} \times \mathrm{h}^{-1}\right]$. In the scientific publications the unit to be used is to indicate the amount of millimoles or milligrams of gas emitted from $1 \mathrm{~m}^{2}$ of soil or 1 kilogram of soil per hour. Most of the available measuring equipment registers the gas concentration in ppm, which determines the number of molecules of the chemical compound (gas) per 1 million molecules of whole mixture of gases (ppm - parts per million). The size of these values is difficult to compare, therefore authors decided to address this issue.

To get the result of a well-defined unit [mg $\left(\mathrm{CO}_{2}\right)$ $\times \mathrm{m}^{-2} \times \mathrm{h}^{-1}$ ] one must determine the difference between the final and initial concentrations $\Delta S$ indicated by the gauge. This will be the concentration of the isolated gas (eg. $\mathrm{CO}_{2}$ ) in the measuring chamber in ppm at a specified time (eg. in 12 minutes). Since the closing of the chamber is not always as smooth and authors noticed a small inertia in measurement with this type of gauges, we suggest to start the measurement 1 minute after its closure. Then just turn on the timer and check the gauge indications. We suggest to complete the measurement in 13 minutes, it means after 12 minutes. It will be a measurement run for 0.2 hours because $1 \mathrm{~h}=60 \mathrm{~min} \times 0.2=12$ minutes. It will be required to calculate the surface area $K$ occupied by the chamber: $K=0.23 \mathrm{~m} \times 0.23 \mathrm{~m}=0.0529 \mathrm{~m}^{2}$.

Since 1 mole of air under normal conditions occupies a volume of $0.0224 \mathrm{~m}^{3}$, in the chamber (wherein the reduced, i.e. corrected volume is $C=0.00969 \mathrm{~m}^{3}$ ) is 0.4326 mole of gas mixture. Taking into account the volume of $C$, we can conclude that under normal conditions for the measuring 
chamber of the described parameters and three gauges in its interior, $1 \mathrm{ppm}$ (as one of a million, i.e. one millionth part of 0.4326 mole) is exactly $0.4326 \times 10^{-6}$ [mole $\times$ $\left.\mathrm{ppm}^{-1}\right]$.

Now, one should only take into account the molar mass of investigated gas, eg. $\mathrm{CO}_{2}$, so that it can be shown that $1 \mathrm{ppm}$ of $\mathrm{CO}_{2}$ in the measuring chamber and under normal conditions is the product of $0.4326 \times 10^{-6}\left[\mathrm{~mole}^{\mathrm{p}} \mathrm{ppm}^{-1}\right]$ $\times 44.01\left[\mathrm{~g}\left(\mathrm{CO}_{2}\right) \times \mathrm{mole}^{-1}\right]=19.0344 \times 10^{-6}\left[\mathrm{~g}\left(\mathrm{CO}_{2}\right) \times \mathrm{ppm}^{-1}\right]$. In summary, $1 \mathrm{ppm}$ of $\mathrm{CO}_{2}$ in the described measuring chamber under normal conditions is the weight of $\mathrm{CO}_{2}$ as close to $0.019\left[\mathrm{mg}\left(\mathrm{CO}_{2}\right) \times \mathrm{ppm}^{-1}\right]$. When under the normal conditions concentration of $\mathrm{CO}_{2}$ in the chamber is increased by $1 \mathrm{ppm}$ or when $\Delta \mathrm{S}=1$ [ppm] it means that the increase was approx. $0.019\left[\mathrm{mg}\left(\mathrm{CO}_{2}\right) \times \mathrm{ppm}^{-1}\right]$.

On the basis of presented calculations one can determine the conversion factor for $1 \mathrm{ppm}$ under the conditions of measuring chamber having a volume $\mathrm{C}=0.00969 \mathrm{~m}^{3}$ per hour out of $1 \mathrm{~m}^{2}$ of the surface from which the emission occur. If the measurement was carried out for 12 minutes, each indicated on the gauge value of $1 \mathrm{ppm}$ of $\mathrm{CO}_{2}$ (which is for the measuring chamber under normal conditions

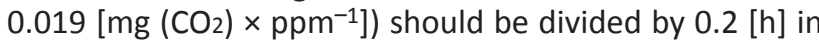
order to expand the values obtained for 12 minute-time-measurement into a full 1 hour and further divide it by the surface of the active chamber $\mathrm{K}=0.0529\left[\mathrm{~m}^{2}\right]$ expanding the result to an area of $1 \mathrm{~m}^{2}$. After conversion the factor for the measuring chamber and for normal conditions in obtained: $0.019 /(0,2 \times 0.0529)=1.7958 \approx 1.8\left[\mathrm{mg}\left(\mathrm{CO}_{2}\right)\right.$ $\left.\times \mathrm{ppm}^{-1} \times \mathrm{m}^{-2} \times \mathrm{h}^{-1}\right]$. Exhalation $E$ will be: $E=\Delta S[\mathrm{ppm}]$ $\times 1.8\left[\mathrm{mg}\left(\mathrm{CO}_{2}\right) \times \mathrm{ppm}^{-1} \times \mathrm{m}^{-2} \times \mathrm{h}^{-1}\right]$, where $\Delta S$ is the difference in indications of the gauge [ppm] after 12 minutes of measurement. Thus, if the increase in the concentration of $\mathrm{CO}_{2}$ in the chamber will be $\Delta \mathrm{S}=160 \mathrm{ppm}$ within $12 \mathrm{mi}-$ nutes than the calculated exhalation is: $E=160 \times 1.8=288$ $\left[\mathrm{mg}\left(\mathrm{CO}_{2}\right) \times \mathrm{m}^{-2} \times \mathrm{h}^{-1}\right]$.

All the above considerations can be determined by the formula:

$$
\begin{gathered}
E=\Delta S \cdot \frac{F \cdot M_{\text {gas }}}{X \cdot K}=\Delta S \cdot \frac{n_{C} \cdot 10^{-6} \cdot M_{\text {gas }}}{X \cdot K} \\
{[E]=\left[p p m \cdot \frac{\mathrm{mol} \cdot \mathrm{ppm}^{-1} \cdot g\left(\mathrm{CO}_{2}\right) \mathrm{mol}^{-1}}{h \cdot \mathrm{m}^{2}}\right]=\left[\frac{g\left(\mathrm{CO}_{2}\right)}{\mathrm{h} \cdot \mathrm{m}^{2}}\right]=\left[\mathrm{g}(\mathrm{CO})_{2} \cdot h^{-1} \cdot \mathrm{m}^{-2}\right]}
\end{gathered}
$$

Example:

Data: $T=296[\mathrm{~K}], p=101800[\mathrm{~Pa}], \Delta S=160[\mathrm{ppm}]$, time of measurement $\mathrm{CO}_{2}=12$ minutes

$$
\begin{gathered}
E=\Delta S \cdot \frac{F \cdot M_{\text {gas }}}{X \cdot K}=\Delta S \cdot \frac{n_{C} \cdot 10^{-6} \cdot M_{\text {gas }}}{X \cdot K}=160 \cdot \frac{\frac{101800 \cdot 0,00969}{8,31 \cdot 296} \cdot 10^{-6} \cdot 44,01}{0,2 \cdot 0,0529}= \\
=160 \cdot \frac{0,4014 \cdot 10^{-6} \cdot 44,01}{0,2 \cdot 0,0529}=0,286\left[\mathrm{~g}(\mathrm{CO})_{2} \cdot h^{-1} \cdot \mathrm{m}^{-2}\right]
\end{gathered}
$$

\section{Remarks on the Method}

This method is widely used in conducting the measurements of gases emission from the soil. It is worth noting that the study using a closed static chamber is subject to certain errors which can be eliminated. The main issue is that this method is not suitable for long-term measurements. This happens when the gas exchange within the chamber is insufficient. Increasing the amount of gases causes an increase in pressure, which in long-term measurements limits the steady growth of concentration. Under extreme conditions it can be assumed to achieve a state of chamber saturation, through which it will be impossible to determine the size of the emission. The increase in gas concentrations in the chamber is not a linear function, but assumes the shape of the flatten out curve over time. The importance of this issue was reported by L. Kutzbach (Kutzbach et al. 2007). The previously conducted studies with typical time of measurement of 30 minutes manifest this problem in a very small extent. In order to eliminate it, the time period for determining the correct emission for a given hour was reduced to the first 13 minutes of measurement.

\section{Acknowledgments}

The authors thank mgr Monika Olewińska for the preparation of the scheme of measuring chamber (fig. 1).

\section{References}

Bekku, Y., Koizumi, H., Oikawa, T., Iwaki, H., 1997. Examination of four methods for measuring soil respiration. Applied Soil Ecology 5(3), 247-254.

Chojnicki, B.H., Michalak, M., Acosta, M., Juszczak, R., Augustin, J., Drösler, M., Olejnik, J., 2010. Measurements of Carbon Dioxide Fluxes by Chamber Method at the Rzecin Wetland Ecosystem, Poland. Polish Journal of Environmental Studies 19(2), 283-291.

Fang, C., Moncrieff, J.B., 2001. The dependence of soil $\mathrm{CO}_{2}$ efflux on temperature. Soil Biology and Biochemistry 33(2), 155-165.

Janssens, I.A., Kowalski, A.S., Longdoz, B., Ceulemans, R., 2000. Assessing forest soil $\mathrm{CO}_{2}$ efflux: an in situ comparison of four techniques. Tree Physiology 20(1), 23-32.

Jensen, L.S., Mueller, T., Tate, K.R., Ross, D.J., Magid, J., Nielsen, N.E., 1996. Soil surface $\mathrm{CO}_{2}$ flux as an index of soil respiration in situ: A comparison of two chamber methods. Soil Biology and Biochemistry 28(10-11), 1297-1306.

Koskinen, M., Minkkinen, K., Ojanen, P., Kämäräinen, M., Laurila, T., Lohila, A., 2014. Measurements of $\mathrm{CO}_{2}$ exchange with an automated chamber system throughout the year: challenges in measuring night-time respiration on porous peat soil. Biogeosciences 11, 347-363.

Krysiak, S., Tołoczko, W., Niewiadomski, A., 2010. CO2 respiration in soils of field ecosystems formed from different origin parent material. Ochrona Środowiska i Zasobów Naturalnych 42, 144-150.

Kusa, K., Sawamoto, T., Hu, R., Hatano, R., 2008. Comparison of the closed-chamber and gas concentration gradient methods for measurement of $\mathrm{CO}_{2}$ and $\mathrm{N}_{2} \mathrm{O}$ fluxes in two upland field soils. Soil Science and Plant Nutrition 54, 777-785.

Kutzbach, L., Schneider, J., Sachs, T., Giebels, M., Nykanen, H., Shurpali, N.J., Martikainen, P.J., Alm, J., Wilmking, M., 2007. $\mathrm{CO}_{2}$ flux 
determination by closed-chamber methods can be seriously biased by inappropriate application of linear regression. Biogeosciences 4 1005-1025.

Maljanen, M., Komulainen, V.M., Hytönen, J., Martikainen, P.J., Laine, J., 2004. Carbon dioxide, nitrous oxide and methane dynamics in borea organic agricultural soils with different soil characteristics. Soil Biology and Biochemistry 36(11), 1801-1808.

Norman, J.M., Kucharik, C.J., Gower, S.T., Baldocchi, D.D., Crill, P.M., Rayment, K., Savage, K., Striegl, R.G., 1997. A comparison of six methods for measuring soil-surface carbon dioxide fluxes. Journal of Geophysical Research 102(D24), 28771-28777.

Papińska, E., Michalska-Hejduk, D., Niewiadomski, A., Tołoczko, W., 2010. $\mathrm{CO}_{2}$ emission from forest and meadow soils on locations of Bolimowski Landscape Park. Ochrona Środowiska i Zasobów Naturalnych 42, 136-143.

Parkin, T.B., Kaspar, T.C., 2003. Temperature Controls on Diurnal Carbon Dioxide Flux: Implications for Estimating Soil Carbon Loss. Soil Science Society of America Journal 67, 1763-1772.

Parkin, T.B., Kaspar, T.C., 2004. Temporal Variability of Soil Carbon Dioxide Flux: Effect of Sampling Frequency on Cumulative Carbon Loss Estimation. Soil Science Society of America Journal 68, 1234-1241.

Paul, A.E. (ed.), 2007. Soil Microbiology, Ecology and Biochemistry. Academic Press, 514.
Pereira de Mello-Ivo, W.M., Salcedo, I.H., 2012. Soil $\mathrm{CO}_{2}$ flux: A method comparison of closed static chambers in a sugarcane field. SociedadeBrasileira de Ciência do Solo 36, 421-426.

Pumpanen, J., Kolari, P., Ilvesniemi, H., Minkkinen, K., Vesala, T., Niinistö, S., Lohila, A., Larmola, T., Morero, M., Pihlatie, M., Janssens, I., Yuste, J.C., Grünzweig, J.M., Reth, S., Subke, J., Savage, K., Kutsch, W., Østreng, G., Zieglerm, W., Anthonim, P., Lindroth, A., Hari, P., 2004. Comparison of different chamber techniques for measuring soil $\mathrm{CO}_{2}$ efflux. Agricultural and Forest Meteorology 123, 159-176.+

Riederer, M., Serafimovich, A., Foken, T., 2014. Net ecosystem $\mathrm{CO}_{2}$ exchange measurements by the closed chamber method and the eddy covariance technique and their dependence on atmospheric conditions. Atmospheric Measurement Techniques 7, 1057-1064

Schneider, M., Kutzbach, L., Schulz, S., Wilmking, M., 2009. Overestimation of $\mathrm{CO}_{2}$ respiration fluxes by the closed chamber method in low-turbulence nighttime conditions. Journal of Geophysical Research $114, \mathrm{G} 03005$.

Tołoczko, W., Niewiadomski, A., 2010. Easy way to assay the amount of $\mathrm{CO}_{2}$ released from soil. Ochrona Środowiska i Zasobów Naturalnych 42, 151-157.

Turcu, V.E., Jones, S.B., Or, D., 2005. Continuous Soil Carbon Dioxide and Oxygen Measurements and Estimation of Gradient-Based Gaseous Flux. Vadose Zone Journal 4, 1161-1169. 